\title{
СТРУКТУРНО-СЕМАНТИЧНІ ОСОБЛИВОСТІ КАУЗАТИВНИХ ПРИСЛІВНИКІВ В УКРАЇНСЬКІЙ МОВІ
}

Кучман I. М. Структурно-семантичні особливості каузативних прислівників в українській мові.

У статті проаналізовані структурно-семантичні особливості каузативних прислівників, які виокремлюються із розряду обставинних. У дослідженні визначено кількісний склад прислівників причини. Прислівники із каузативною семантикою погруповано за відтінками причинової семантики.

Ключові слова: каузативність, причиновість, причина, каузативна конструкція, прислівник.

Кучман И. Н. Структурно-семантические особенности каузативних наречий в украинском языке.

В статье проанализированы структурно-семантические особенности каузативних наречий, которые выделяются из разряда обстоятельственных. В исследовании определен количественный состав наречий причины. Наречия с каузативной семантикой сгруппированы согласно оттенкам причинной семантики.

Ключевые слова: каузативность, причинность, причина, каузативная конструкция, наречие. 
Kuchman I. M. Structural-semantic peculiarities of causative adverbs in Ukrainian language.

The article analyzes structural-semantic peculiarities of causative adverbs which are singled out of adverbial modifiers. The research defines quantitative composition of causative adverbs. The adverbs with causative semantics are grouped according to causal shades of meaning.

Key words: causativity, causality, cause, causative construction, adverb.

Традиційно прислівник кваліфікують як повнозначну незміннювану частину мови із загальним категоріальним значенням непроцесуальної ознаки дії, стану або якості [5, с. 446-447; 7, с. 295]. За твердженням одних учених, цей клас слів поєднує в собі, окрім граматичного, лексичне значення [5, с. 448-449; 6, с. 430]. Протилежну думку обстоюють І. Р. Вихованець та К. Г. Городенська, які тлумачать прислівник як особливий синтагматичний клас слів, позбавлений специфічного лексичного значення, такого, яке властиве іменнику, прикметнику, дієслову або числівнику. Прислівник має семантикосинтаксичне значення i виконую функцію ознаки ознаки [2, с. $185 ; 1$, с. $298-300]$.

У реченні прислівник займає лише придієслівну або приприкметникову позиції і виражає додаткову ознаку щодо основної ознаки (динамічної або статичної). Такі відношення між ознаковими словами можуть бути різнотипними: атрибутивними, просторовими, часовими, причиновими, цільовими.

У підходах до класифікації прислівників на значеннєві розряди переважає синтаксичний принцип поділу. Такий поділ зазвичай грунтується на семантико-синтаксичному відношенні, яке складається в реченні між дієсловом або прикметником i залежним від них прислівником. Каузативні відношення, як різновид обставинних відношень між предикатом речення або іншим членами речення i залежним прислівником, виражають обставинні прислівники, а саме прислівники причини, як їх традиційно називають [5, с. 453; 3, с. 243]. M. І. Степаненко пропонує термін каузальні прислівники на позначення одиниць із причиново-цільовою семантикою [4]. У пропонованій роботі прислівники, які актуалізують каузативні відношення, називаємо каузативними прислівниками. Як підтип каузативних відношень, що здатні конкретизуватися в простому реченні за допомогою адвербіального поширювача, відносимо причинові. 
Оскільки каузативні прислівники не були об'єктом ретельного вивчення, у статті поставлено за мету розглянути всі структурні і семантичні особливості цього типу каузативних операторів.

Каузативні прислівники, які вносять причинове обгрунтування певної ознаки, вираженої предикатом, входять до складу обставинних, i разом із прислівниками часу, місця і допустовості вводять певний уточнювальний компонент щодо умов і обставин, за яких відбувається дія. Значення часу і місця розпадаються на детальніші відтінки, а значення причини в прислівниках виражене найбільш узагальнено. Пояснюється це тим, що «українська мова надзвичайно багата прислівниками часу та місця i бідна прислівниками причини...» [3, с. 243]. Функція вираження всього розмаїття каузативних відношень на рівні простого ускладненого речення покладена на прийменникововідмінкові форми, а на рівні складного речення - на сполучники. Прислівники - це по суті менша кількісно, але якісно ідентична група морфологізованих прийменниково-відмінкових форм. Порівняйте паралельне вживання в мові художніх творів в одного й того ж автора прислівника зозла і прийменниково-відмінкової сполуки зо зла в таких реченнях: Зозла вп'явся [Чіпка] руками в свою нечесану куштру (П. Мирний); Собаки! - i Василь зо зла плюнув (П. Мирний). Лише незначна кількість прийменниково-відмінкових форм із значенням спричинення адвербіалізувалась і за своєю будовою є застиглими або змертвілими формами, що зберегли відповідну семантику. Однак, слід зауважити, що «адвербіалізація є одним із засобів поповнення класу прислівників і нині» [7, с. 297]. Зрештою, постійне відтворення в мовленні певних прийменниково-відмінкових форм, із каузативним значенням зокрема, спричинятиме їх перехід у розряд прислівників, як це свого часу сталось із сполуками зо зла, з дуру.

У каузативних конструкціях, актуалізованих із причиновими прислівниками, консеквент виражений у розгорнутій формі (переважно дієслівним предикатом), а антецедент виражений у згорнутій формі (прислівником). Наприклад у реченні $A$ чи й було таке, а може, то йому сn'яну примарилось? 3 твору Романа Іваничука консевент йому примарилось, а антецендент сn'яну. Дослідники звертають увагу на співвіднесеність прислівників, зокрема причини, із відповідними підрядними детермінатними (обставинними) частинами у складнопідрядному реченні, зважаючи на їх спеціалізованість у вираженні такого ж типу відношень, яким пов’язується підрядна 
частина із головною $[1$, с. $302 ; 8$, с. 67]. Звідси, особливістю каузативних прислівників $є$ їх здатність конденсувати в одній словоформі значення підрядної частини, у яку він може розгортатись. Пор.: Він спересердя кинув у мене черевиком. - Він кинув у мене черевиком, бо був сердитий або Він кинув у мене черевиком, тому щчо розсердився. Проте, на відміну від підрядних речень, у яких сполучники можуть відтворювати різні відтінки каузативної семантики, прислівники - як кількісно, так і якісно обмежена група одиниць, що можуть виражати тільки загальнопричинове значення у реченні.

У пропонованому дослідженні визначено кількісний склад каузативних прислівників - 34 одиниці. До них ми відносимо такі форми, що мають семантику причини: спросоння, спроста, спохвату, спересердя, сп'яну, спрожогу, згарячу, знічев'я, зопалу, зосліпу, зостраху, здуру, знестямки, поневолі, віднехотя, принагідно, тому, чому (чом), чомусь, чогось, недарма, недаром, нащось, нізащо, неспроста, недурно, безпричинно, безпредметно, безпідставно, даремно, дарма, дурно, вимушено, умисне. Наприклад: Певно, спросоння в мене голова не дуже варила, бо я майже нічого не міг збагнути (Л. Смілянський); Члени військової ради знали, щзо майор з иифрувального відділу спроста не заходив на засідання (В. Кучер); Василина ... так швидко побігла до возів, щзо спохвату на перелазі загубила торбу з хлібом (І. Нечуй-Левицький) Осавула... спересердя пішов до пана й розказав, що молотники крадуть 3 панського току жстоо... (І. Нечуй-Левицький); - Який паспорт? - сn'яну не міг второпати приятель... (О. Гончар); Утекла та спрожсоу як улетить у хату, аж мачуху злякала... (Б. Грінченко); Саркісьян, якому належала галоша ... і який був черговим, згарячу вихопив галошу, надів ї̈ на босу носу й подався (I. Багряний); На привалах біля вогнища він травив знічев'я мисливські байки (А. Кокотюха); Зопалу я шарпонув держак на себе, $і$ кочерга врізалась у стіну (Р. Андріяшик); Вівці ... тичялися зосліпу то в той, то в той бік (П. Загребельний); Він кричав так люто... щзо я, зостраху, кинувся геть із кузні... (Б. Грінченко); - Це чи не Афонька здуру пустив їх сюди? (Б. Антоненко-Давидович); Василина вхопила торбу $i$, як птиця, вилетіла знестямки на фургон туди, де було найгустіше дівчат (І. Нечуй-Левицький); Але ви для мене не сила, і мені вас по-людськи шкода. Ось чому я намагався попередити кровопролиття (Р. Андріяшик); Це він тільки тепер так чогось засушився (Д. Гуменна); Улянщі завжди чомусь здається, що Людмила Степанівна немов не все сказала, що є в неї якісь невідомі для дівчинки () І. М. Кучман, 2012. 
слова (О. Донченко); Він раптом аж перехилився на стіл $i$ заговорив нащось пошепки... (А. Головко); [Принщеса:] Недарма ж я сиділа там на вишиі - майстерниця зробилася з пастушки (Леся Українка); - Tu, Мокрино, неспроста приходиш пізно додому (І. Нечуй-Левицький); Недурно Чіпка жалкував про хліб: він був у них, як розважений... (П. Мирний); Ви, Семене Івановичу, грамотні, знаєте, усе знаєте, як важко чоловікові терпіти $i$ переносити худу славу безпричинно (Г. Квітка-Основ'яненко); $Я$ не люблю безпредметно тужити (І. Франко); ... даремно він витрачає останні сили на пошуки дівчинки, бо їі немає, давно вже немає в лісі (О. Донченко); - Дурно заходив! Нас дома не було... (І. Нечуй-Левицький); ... вона кожного... спочатку як слід вилає (здебільиого нізащо), а тоді вже розпитає... (О. Гончар).

Зі структурного погляду каузативні прислівники функціонують у реченнях переважно при дієслівному предикаті. Така модель $є$ базовою. Наприклад: Зопалу він погнав коня на доріжку, щзоб розвідати ї̈ до кінця (О. Гончар). Каузативні прислівники також можуть обгрунтовувати ознаку, яка виражена в реченні прикметником у складі дієслівного складеного присудка, прикметником у позиції означення, прикметником або дієприкметником у позиції відокремленого означення. Наприклад: I одразу ж з вікна з'явилась непричесана спросоння Вірунька (О. Гончар); Матюха хриплим голосом сп'яну оголосив загальні збори обухівської громади одкритими (А. Головко); Очманілі спросоння, вихоплювались з вагонів, кидались у світ титанічних кошмарів, моторошних видінь (О. Гончар); На небі, мов спохвату забутий якимсь таємничим женцем, висів блідий місячний серп (Р. Андріяшик).

За відтінками каузативної семантики аналізовані прислівники можна поділити на три групи: 1) конкретно каузативні; 2) приховано каузативні; 3) антикаузативні.

До конкретно каузативних прислівників відносимо лексеми, які у своєму значенні мають чітку вказівку на причину. До прислівників конкретної каузативної семантики відносимо такі одиниці: спросоння, спохвату, спересердя, сп'яну, спрожогу, згарячу, знічев'я, зопалу, зосліпу, здуру, знестямки. Наприклад: Може, обібрано когось, може, хтось голову комусь проломив сп'яну (А. Головко).

До приховано каузативних прислівників відносимо лексеми, які не мають чіткої вказівки на причину. Такі прислівники вказують «натяком» на існування певної причини, яка не виражена безпосередньо. 
Розкриття такої причини припадає на близьке валентне оточення, різної широти контекст, або така причина виступає як неексплікована. До прислівників прихованої каузативної семантики відносимо такі: нащось, недарма, недаром, недаремно, неспроста, недурно, чомусь, чогось. Наприклад: - Це вже моя смерть приходила по мене! Це недурно прилетіла в хату ластівка, - сказала Нимидора дочијі (І. НечуйЛевицький); Нащось погладивщи обкладинку, він поклав альбом на полищю $і$ повернувся назад до столу з тим же відчуженим виразом (Р. Андріяшик); Золоте серие $i$ купа розуму... Недаремно він скінчив Дублянський агрономічний інститут (В. Реймонт).

До антикаузативних прислівників відносимо лексеми, які займають відповідну обставинну позицію і формально вказують на причину, проте за своїм значенням вони виражають відсутність певної причини. Прислівники цієї групи ілюструють розбіжність між причиновістю логічною і лінгвістичною. Попри відоме твердження, що у світі немає нічого безпричинного, каузативність мовна широко використовує арсенал засобів, які вказують на формальну відсутність причини, за якою постає їх невизначеність, невідомість або неважливість для мовця. До каузативних прислівників невизначеної семантики відносимо такі: випадково, мимовільно, безпричинно, безпредметно, безпідставно, даремно, дурно, нізащзо. Наприклад: Гасав мотоциклом, своєю скаженою «Явою» по всьому надбережжю, доки врізався у натовп дітей піонерського табору... Сталося ненавмисне, розігнав моточикл і не стримав, та хіба це виправдання? (О. Гончар).

Каузативні прислівники невизначеної семантики вступають в антонімічні відношення із прислівниками прихованої семантики: навмисне - ненавмисне, даремно - недаремно, дурно - недурно. Щодо валентного оточення, то прислівники навмисне, недаремно, недурно вказують на існування мотиву, про який може йтись у попередньому або наступному контексті, тоді як прислівники ненавмисне, даремно, дурно можуть мати пояснювальну аргументацію, доведення або не мати іiі. Пор: Гасав мотоциклом, своєю скаженою «Явою» по всьому надбережжю, доки врізався у натовп дітей піонерського табору... Сталося ненавмисне, розігнав мотоиикл $i$ не стримав, та хіба изе виправдання? - Мати на останнім місяці вагітності виходила 3 вагона, і ї̈ ударив в живіт гострим кутом скрині якийсь пасажир. Він це зробив ненавмисне (В. Сосюра). 
Значення невизначеності нівелюється у випадку вживання таких прислівників із запереченням. У таких ситуаціях напевне стверджується факт існування причини. Тому прислівники, вжиті із заперечною часткою, переходять у розряд приховано каузативних. Наприклад: Не часто иее з нею [Шпачихою] трапляється і ніколи не безпричинно, завжди на те буде поштовх внутрішній, тільки ій відомий (О. Гончар).

Таким чином, на рівні простого ускладненого речення каузативність може бути представлена за допомогою кількісно невеликої і якісно нерозгалуженої групи прислівників. Каузативні прислівники виражають загальнопричинове значення. Пропонуємо їх поділ за семантичними відтінками на конкретнокаузативні, прихованокаузативні та антикаузативні. Антецедент каузативної конструкції має згорнуте вираження, а консеквент представлений переважно дієслівним предикатом.

\section{Література}

1. Вихованець I. Р. Теоретична морфологія української мови : Академічна граматика української мови / I. Р. Вихованець, К. Г. Городенська; [за ред. І. Р. Вихованця]. - К. : Унів. вид-во «Пульсари», 2004. - 400 с.

2. Вихованець I. Р. Частини мови в семантико-граматичному аспекті/ Іван Романович Вихованець. - К. : Наук. думка, 1988. - 256 с.

3. Леонова М. В. Сучасна українська літературна мова : Морфологія / Марія Василівна Леонова. - К. : Вища школа, 1983. - 264 с.

4. Степаненко М. І. Каузальні прислівники у функції семантичних поширювачів реченнєвої структури / М. І. Степаненко // Вісник Луганського держ. пед. ун-ту ім. Тараса Шевченка. Філологічні науки: Мовознавство. - 1999. - № 5 (15). - С. 15-26.

5. Сучасна українська літературна мова : [підручник для студ. філол. спец. вищ. навч. закладів]/ $\quad$ А. П. Грищенко, Л. І. Мацько, М. Я. Плющ, Н. І. Тоцька, I. М. Уздиган; [за ред. А. П. Грищенка]. - [2-ге вид., переробл. і допов.] - К. : Вища школа, 1997. - 493 с.

6. Сучасна українська літературна мова : Морфологія / [за ред. І. К. Білодіда]. К. : Наук. думка, 1969. - 583 с.

7. Сучасна українська літературна мова : [підручник] / М. Я. Плющ, С. П. Бевзенко, Н. Я. Грипас та ін.; [за ред. М. Я. Плющ]. - [4-те вид., стер.]. - К. : Вища школа, 2003. - $430 \mathrm{c.}$

8. Щукіна І. А. Спеціалізованість причинових прийменників у трансформації / I. А. Щукіна // Лінгвістичні студії : зб. наук. праць. - Донецьк : ДонНУ, 2004. Вип. 12. - С. 64-68. 